\title{
Serum folate levels in bipolar disorder: a systematic review and meta-analysis
}

\author{
Yung-Chi Hsieh', Li-Shiu Chou', Ching-Hua Lin ${ }^{1}$, Hung-Chi Wu', Dian-Jeng Li ${ }^{1 *}$ (D) and Ping-Tao Tseng ${ }^{2,3^{*}}$
}

\begin{abstract}
Background: Bipolar disorder (BD) is a major psychiatric illness, however its physiopathology is unclear. The role of folate in the physiopathology of $\mathrm{BD}$ is controversial. We conducted this systematic review and meta-analysis to investigate the effect of folate in BD patients.

Methods: We performed a thorough literature study of the PubMed, Embase, ScienceDirect, ClinicalKey, Cochrane Library, ProQuest, Web of Science, and ClinicalTrials.gov databases until December 21st, 2018. Random effects metaanalysis was conducted.

Results: Six articles involving 481 patients with BD and 760 controls were included. The meta-analysis results suggested that serum folate levels in the patients with BD were significantly lower than those in the controls (Hedges' $g=-0.211,95 \%$ confidence interval $=-0.391$ to $-0.031, p=0.021$ ).

Conclusion: The current meta-analysis show it might be association between lower serum folate levels and patient with BD. However, we could not distinguish the potentially confounding effects of mood states on the folate levels. Further prospective studies including subjects with different mood states and possible physiopathology are warranted to investigate the association between folate deficiency and the etiology of BD.
\end{abstract}

Keywords: Folate, Folic acid, Biomarker, Meta-analysis, Bipolar disorder

\section{Highlight}

1. Folate is a key element in neurotransmitter synthesis and had been found to be abnormally synthesized in numerous psychiatric diseases.

2. The current meta-analysis showed that serum folate levels in individuals with bipolar disorder (BD) were lower than in healthy controls.

3. To provide clearer information about the role of folate in physiopathology of $\mathrm{BD}$, future investigations should be warranted.

\section{Background}

Bipolar disorder (BD) is a major health concern due to the difficulty in achieving complete remission $[1,2]$. It has been reported that up to two-thirds of patients diagnosed with BD have moderate to severe disease, [3] and that more than half of patients experience recurrence $[4,5]$ or subthreshold

\footnotetext{
* Correspondence: edcrfvm45@gmail.com; ducktseng@gmail.com

${ }^{1}$ Kaohsiung Municipal Kai-Syuan Psychiatric Hospital, No.130, Kaisyuan 2nd Rd., Lingya Dist, Kaohsiung City 802, Taiwan

${ }^{2}$ WinShine Clinics in Specialty of Psychiatry, Kaohsiung City, Taiwan

Full list of author information is available at the end of the article
}

episodes [6] despite regular treatment. Furthermore, the symptoms of $\mathrm{BD}$ may negatively affect social-economic performance and interpersonal relationships among $\mathrm{BD}$ patients, $[7,8]$ and it is associated with a predominantly functional impairment, lower quality of life, and death due to suicide or comorbid physical diseases $[9,10]$. Accordingly, BD is the sixth leading cause of disability globally [11]. Studies focusing on the physiology of BD may help to elucidate its etiology and lead to new treatment strategies.

In an effort to understand the physiopathology underlying $\mathrm{BD}$, researchers have attempted to identify potential biomarkers for patients with BD and apply the new field of "precision psychiatry." [12-14] Neurotrophic factors such as brain-derived neurotrophic factor (BDNF) $[15,16]$ and transforming growth factor beta 1 (TGF- $\beta 1$ ) [17] have been proposed as potential peripheral biomarkers in $\mathrm{BD}$. In addition, purinergic abnormalities leading to uric acid levels variations have been recently reported in $\operatorname{BD}[18,19]$. Furthermore, $\mathrm{BD}$ has been associated with a poor nutritional status, $[20,21]$ as patients with $\mathrm{BD}$ have been reported to

(c) The Author(s). 2019 Open Access This article is distributed under the terms of the Creative Commons Attribution 4.0 International License (http://creativecommons.org/licenses/by/4.0/), which permits unrestricted use, distribution, and reproduction in any medium, provided you give appropriate credit to the original author(s) and the source, provide a link to the Creative Commons license, and indicate if changes were made. The Creative Commons Public Domain Dedication waiver (http://creativecommons.org/publicdomain/zero/1.0/) applies to the data made available in this article, unless otherwise stated. 
be more likely to consume unhealthy prepared food without essential vitamins, minerals and $n-3$ fatty acids [22].

Folate is a water-soluble vitamin (Vit. B9), which is vital for cellular activity and immune and nervous system functions. Folate can reduce the level of homocysteine and act as a precursor of methionine and S-adenosyl methionine, which are major sources of methyl groups in the brain [23]. Folate has also been reported to be involved in the synthesis of neurotransmitters and many other metabolic pathways, which may be associated with exacerbations of psychiatric disorder [24, 25]. Folate is also essential for deoxyribonucleic acid (DNA) repair, and it has been intimately associated with methylation and the formation of neurotransmitters in the central nervous system, such as serotonin [26-28]. Previous studies have investigated the association between levels of folate and BD. A cross-sectional study indicated that the mean folate level in patients was significantly lower than in controls, and a positive correlation was found between depression and low folate levels [29]. However, another study including patients with manic episodes demonstrated no significant differences in folate level between the patients and healthy control [30]. In addition, a clinical trial on biomedical predictors of treatment response in patients with bipolar depression also found no significant difference in folate level between patients who received lamotrigine and controls [31].

The inconsistencies in the results of differences in folate levels between patients with BD and healthy controls raise a crucial question about which level of folate may exert an effect on exacerbations of BD. A previous systematic review and meta-analysis reported that low folate status was associated with depression [32]. Decreased folate levels have been also proposed as possible biomarker of schizophrenia, according to a recent review [33]. However, there is still a need for systematic reviews or meta-analyses summarizing previous literature with regards to BD. Therefore, we conducted a systematic review and meta-analysis to investigate the effect of folate on patients with $\mathrm{BD}$, and to explore differences in folate levels between patients with $\mathrm{BD}$ and healthy subjects. We hypothesized that the level of folate among patients with BD may be lower than that among healthy individuals, which might reflect the potential physiopathology of BD.

\section{Methods and materials}

We complied with the Preferred Reporting Items for Systematic Reviews and Meta-Analyses (PRISMA) guidelines [34] (see Additional file 1 and Additional file 2). The current meta-analysis followed the protocol which was not published a priori.

\section{Eligibility criteria}

The inclusion criteria were: (a) studies in humans; (b) observational studies, including a cross-sectional or cohort study design; (c) investigating the peripheral levels of folate between patients diagnosed with BD and those of the healthy controls; (d) the mood status investigated could be manic episode, depressive episode, euthymic episode, or mixed episode; (e) BD patients with/without concomitant medication; (f) the peripheral folate could be that of serum, plasma, or whole blood; and (g) formal published studies in journal articles.

The exclusion criteria consisted of (a) non-human studies; (b) non-clinical studies, such as review articles or case reports; (c) not formal published studies in journal articles, such as meeting abstracts or posters; and (d) not investigating peripheral folate levels in BD patients and controls.

\section{Search strategy and study selection}

Two well-trained authors (DJ Li and YC Hsieh) conducted a systematic literature search from inception until December 21st, 2018 with the following keywords: "(vitamin B12 OR cobalamin OR folate OR folic acid OR folacin OR vitamin B9 OR homocysteine OR methionine) AND ((bipolar depression) OR (bipolar mania) OR (mania) OR (bipolar disorder))" on PubMed, Embase, ScienceDirect, ClinicalKey, Cochrane Library, ProQuest, Web of Science, and ClinicalTrials.gov platforms for all eligible studies. To include as many studies as possible, we did not set any limitation in language (Additional file 1: Table S3). We were also handsearched the reference lists of the included articles and recent reviews to identify more articles [35-39].

The titles and abstracts of all results for potential eligibility screened by the two authors (DJ Li and YC Hsieh) independently. A final list of included studies was achieved after both authors reviewed the full-text articles of potentially eligible papers. A third reviewer (PT Tseng) helped to resolve inconsistencies through discussion.

\section{Outcome settings}

The outcome was the difference in peripheral folate levels between patients with $\mathrm{BD}$ and control groups (calculated as Hedges' $g$ statistic and corresponding 95\% confidence intervals (CIs) and $p$ values). Because of presumed differences in the tools used to detect folate among the studies, we did not choose differences in means as the effect sizes (ESs) of our primary outcome. The control groups were defined as those without BD or any other psychiatric illness. We preferred to choose control groups consisting of healthy (asymptomatic) subjects, if data were available. We contacted the primary authors to request the original data, when data were not available from the included studies. We contacted the authors via email on two conditions if necessary (a second email was sent a week later if no response was received following the initial email). Of all the papers we found, if there was no relevant data concerning folate levels, we attempted to use another compatible statistical parameter (e.g. $p$ value 
and sample size) to estimate the ESs according to the proto$\mathrm{col}$ in the Comprehensive Meta-Analysis manuals and guidance on the Comprehensive Meta-Analysis website [40] to convert and pool the ESs into Hedges' $g$.

\section{Methodological quality appraisal}

The Newcastle-Ottawa scale (NOS) was used to assess the quality of the included studies. In short, the NOS was based on a version previously used in a meta-analysis study published in the British Journal of Psychiatry in 2013, of which scores ranging from zero to sixteen (Additional file 1: Table S1) [41]. The NOS were accessed by the two authors (DJ Li and YC Hsieh) independently. A third reviewer (PT Tseng) helped to resolve inconsistencies through discussion.

\section{Meta-analysis procedure}

With regard to the anticipated heterogeneity in the basic study population, we conducted the meta-analyses with a random effects model. As mentioned above, the primary ES was estimated as Hedges' $g$ with 95\% CIs to compare folate levels in patients with BD versus controls.

\section{Sensitivity test, heterogeneity, publication bias, and meta-regression}

Sensitivity testing with the "leave-one-out sensitivity analysis" test was used to evaluate whether or not the results of the meta-analysis was caused by any outliers within the recruited studies [42]. Heterogeneity was assessed using the Cochrane $\mathrm{Q}$ test and its corresponding $p$ value [43]. We conducted meta-regression analyses with unrestricted maximum likelihood random-effects when data on each potential moderator was provided by at least ten different studies. We assessed publication bias through the inspection of funnel plots [44] and with the Egger's regression test [45]. We used the Duval and Tweedie's trim-and-fill procedure to adjust the potential publication bias, when evidence of publication bias was found [46]. The current meta-analyses were performed using the Comprehensive Meta-Analysis software, version 3 (Biostat, Englewood, NJ). The threshold for statistical significance was set at a two-tailed $p$-value $<0.05$.

\section{Results}

\section{Study selection}

Figure 1 is the summary of details of the search results. In brief, a total of 12 studies were selected at the full-text review stage, of which 6 were excluded for a variety of reasons (see Fig. 1). Additional file 1: Table S2 presented a list of the excluded articles. In total, six articles met the inclusion criteria, and their details are summarized in Tables 1 and $2[29,47-51]$.

\section{Characteristics and methodological quality of the included studies}

All of the included studies provided comparisons of differences in serum folate levels between patients with BD and controls (BD group: $n=481$, mean age $=37.9$ years, mean female proportion $=56.1 \%$; controls without BD: $n=760$, mean age $=41.1$ years, mean female proportion $=55.5 \%)$. None of the included studies compared peripheral folate levels in plasma or whole blood. Of these six studies, two $[29,50]$ measured folate levels in patients with mania, two $[49,51]$ in patients with euthymia, and two $[47,48]$ did not specify the mood state. Of these six studies, two $[47,48]$ consisted of patients on medication, and the other four studies did not mention information about medication.

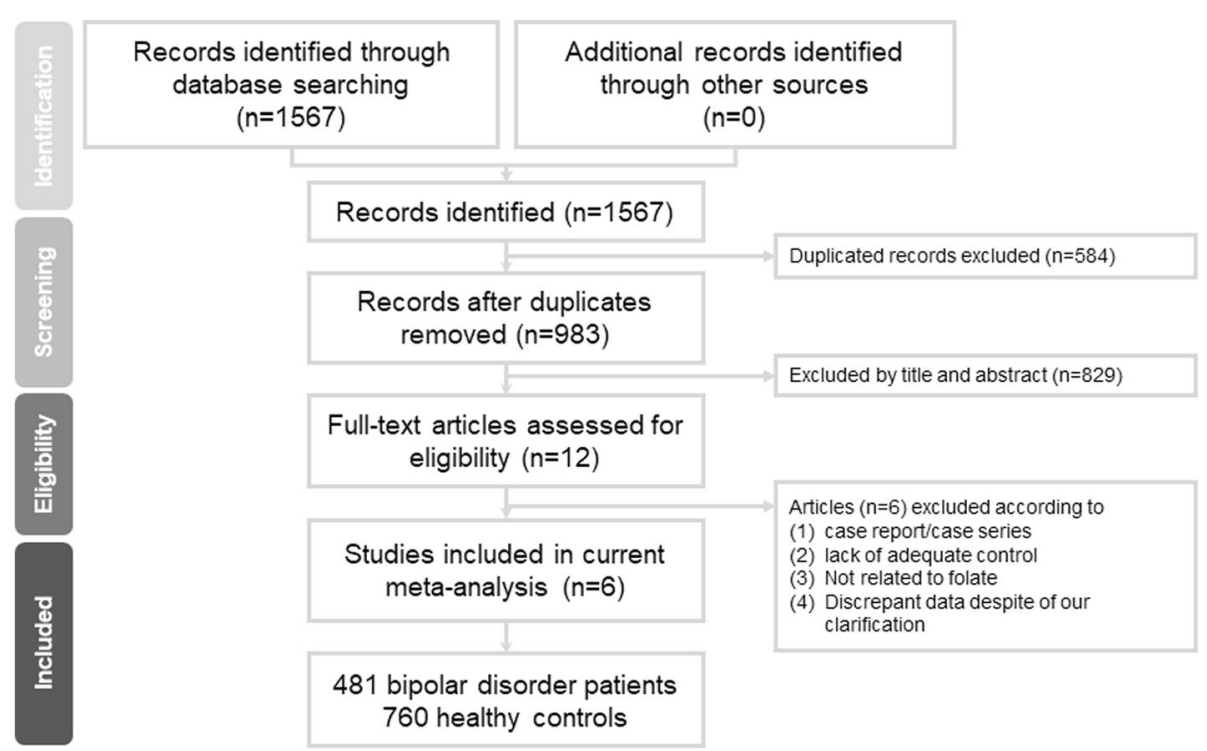

Fig. 1 the flowchart of the current meta-analysis 
Table 1 Characteristics of the included studies

\begin{tabular}{|c|c|c|c|c|c|c|c|c|c|}
\hline Author (year) & $\begin{array}{l}\text { Study } \\
\text { design }\end{array}$ & Criteria & $\begin{array}{l}\text { bipolar } \\
\text { subtype }\end{array}$ & $\begin{array}{l}\text { symptom } \\
\text { severity }\end{array}$ & $\begin{array}{l}\text { Mood state } \\
\text { and subjects' } \\
\text { characteristics }\end{array}$ & $\begin{array}{l}\mathrm{n} \\
\text { (male/ } \\
\text { female) }\end{array}$ & $\begin{array}{l}\text { Mean } \\
\text { age }\end{array}$ & Source and assay & Comorbidities and exclusion criteria \\
\hline $\begin{array}{l}\text { Doganavsargil } \\
\text { Baysal, G.O. } \\
\text { (2013) }\end{array}$ & $\begin{array}{l}\text { case- } \\
\text { control } \\
\text { study }\end{array}$ & $\begin{array}{l}\text { DSM- } \\
\text { IV-TR }\end{array}$ & $\begin{array}{l}\text { bipolar } \\
\text { I disorder }\end{array}$ & maintain & $\begin{array}{l}\text { Euthymic } \\
\text { patient } \\
\text { Healthy } \\
\text { control }\end{array}$ & $\begin{array}{l}60(n / \\
\text { a) } \\
20(n / \\
\text { a) }\end{array}$ & $\mathrm{n} / \mathrm{a}$ & Serum, n/a & $\begin{array}{l}\text { Patients who had neurologic } \\
\text { diseases, cardiovascular diseases, } \\
\text { renal diseases, diabetes mellitus, } \\
\text { hypo/hyperthyroid- ism, non- } \\
\text { psychotropic drug use that could } \\
\text { affect HCY levels, substance abuse, } \\
\text { an IQ score below } 80 \text { based on the } \\
\text { WAIS-R test (Epir and Iskit, 1972), a } \\
\text { history of electroconvulsive therapy } \\
\text { during the previous } 6 \text { months, or pa- } \\
\text { tients who tested positive for bio- } \\
\text { chemical markers suggestive of } \\
\text { abnormal thyroid, liver or renal func- } \\
\text { tions were not included in the study. }\end{array}$ \\
\hline $\begin{array}{l}\text { Ezzaher, A. } \\
\text { (2011) }\end{array}$ & $\begin{array}{l}\text { case- } \\
\text { control } \\
\text { study }\end{array}$ & $\begin{array}{l}\text { DSM- } \\
\text { IV }\end{array}$ & $\begin{array}{l}\text { bipolar } \\
\text { I disorder }\end{array}$ & $\mathrm{n} / \mathrm{a}$ & $\begin{array}{l}\text { Depressive, } \\
\text { manic, } \\
\text { euthymic } \\
\text { patient } \\
\text { Healthy } \\
\text { control }\end{array}$ & $\begin{array}{l}92(62 / \\
30) \\
170 \\
(79 / 91)\end{array}$ & $\begin{array}{l}36.0 \pm \\
11.1 \\
43.7 \pm \\
14.2\end{array}$ & $\begin{array}{l}\text { Serum, microparticle } \\
\text { enzyme immunoassay on } \\
\text { Elecsys } 2010\end{array}$ & $\begin{array}{l}\text { The exclusion criteria were age }<18 \\
\text { years, other psychiatric illnesses, } \\
\text { epilepsy, mental retardation, } \\
\text { hormone therapy, history of vitamin } \\
\text { use, diabetes, cardiovascular disease, } \\
\text { thyroid dysfunction, liver disease, or } \\
\text { renal dysfunction. }\end{array}$ \\
\hline $\begin{array}{l}\text { Diass, V.V. } \\
(2009)\end{array}$ & $\begin{array}{l}\text { case- } \\
\text { control } \\
\text { study }\end{array}$ & $\begin{array}{l}\text { DSM- } \\
\text { IV }\end{array}$ & $\begin{array}{l}\text { bipolar } \\
\text { | disorder }\end{array}$ & maintain & $\begin{array}{l}\text { Euthymic } \\
\text { patient } \\
\text { Healthy } \\
\text { control }\end{array}$ & $\begin{array}{l}65(24 / \\
41) \\
49(14 / \\
35)\end{array}$ & $\begin{array}{l}37.8 \pm \\
10.5 \\
33.6 \pm \\
9.8\end{array}$ & $\begin{array}{l}\text { Serum, } \\
\text { electrochemiluminescence } \\
\text { immunoassay }\end{array}$ & $\begin{array}{l}\text { Patients with neurological disorders, } \\
\text { previous head trauma, physical } \\
\text { illnesses requiring medical } \\
\text { intervention, substance abuse, or an } \\
\text { ECT course in the preceding } 6 \\
\text { months were excluded. }\end{array}$ \\
\hline $\begin{array}{l}\text { Ozbek, Z. } \\
\text { (2008) }\end{array}$ & $\begin{array}{l}\text { case- } \\
\text { control } \\
\text { study }\end{array}$ & $\begin{array}{l}\text { DSM- } \\
\text { IV }\end{array}$ & $\begin{array}{l}\text { Bipolar } \\
\text { disorder }\end{array}$ & $\mathrm{n} / \mathrm{a}$ & $\begin{array}{l}\text { Unspecified } \\
\text { mood patient } \\
\text { Healthy } \\
\text { control }\end{array}$ & $\begin{array}{l}197 \\
(74 / \\
123) \\
238 \\
(67 / \\
171)\end{array}$ & $\begin{array}{l}40.6 \pm \\
12.2 \\
41.3 \pm \\
12.7\end{array}$ & $\begin{array}{l}\text { Serum, } \\
\text { electrochemiluminescence } \\
\text { immunoassay }\end{array}$ & $\begin{array}{l}\text { None of the subjects had significant } \\
\text { neurological comorbidity, epilepsy, } \\
\text { mental retardation or a history of } \\
\text { substance abuse. } \\
\text { None of the subjects presented with } \\
\text { current or past history of } \\
\text { cardiovascular disease, } \\
\text { endocrinological and metabolic } \\
\text { disease, or a family history of } \\
\text { coronary heart disease. }\end{array}$ \\
\hline $\begin{array}{l}\text { Lerner, V. } \\
\text { (2006) }\end{array}$ & $\begin{array}{l}\text { case- } \\
\text { control } \\
\text { study }\end{array}$ & $\begin{array}{l}\text { DSM- } \\
\text { IV }\end{array}$ & $\begin{array}{l}\text { bipolar } \\
\text { I disorder }\end{array}$ & acute & $\begin{array}{l}\text { Mania, } \\
\text { inpatient } \\
\text { Healthy } \\
\text { control }\end{array}$ & $\begin{array}{l}22(n / \\
\text { a) } \\
250 \\
(156 / \\
94)\end{array}$ & $\begin{array}{l}\mathrm{n} / \mathrm{a} \\
42.17 \pm \\
14.2\end{array}$ & $\begin{array}{l}\text { Serum, } \\
\text { Electrochemiluminescence }\end{array}$ & $\mathrm{n} / \mathrm{a}$ \\
\hline $\begin{array}{l}\text { Hasanah, C.I. } \\
\text { (1997) }\end{array}$ & $\begin{array}{l}\text { case- } \\
\text { control } \\
\text { study }\end{array}$ & $\begin{array}{l}\text { DSM- } \\
1 \|-R\end{array}$ & $\begin{array}{l}\text { bipolar } \\
\text { I disorder }\end{array}$ & acute & $\begin{array}{l}\text { Mania, } \\
\text { inpatient } \\
\text { Healthy } \\
\text { control }\end{array}$ & $\begin{array}{l}45(24 / \\
21) \\
33(13 / \\
20)\end{array}$ & $\begin{array}{l}30.0 \\
29.0\end{array}$ & serum, the IMx system & $\begin{array}{l}\text { The exclusion criteria were, mood } \\
\text { incongruent psychotic features, } \\
\text { concomitant medical illness, } \\
\text { substance misuse, pregnancy, } \\
\text { puerperium and those on drug } \\
\text { treatment. Those with noticeable } \\
\text { weight loss by close relatives were } \\
\text { also excluded. }\end{array}$ \\
\hline
\end{tabular}

Abbreviation: DSM-IV-TR Diagnostic and Statistical Manual of Mental Disorders, 4th edition, Text-Revision; DSM-IV Diagnostic and Statistical Manual of Mental Disorders, 4th edition; DSM-III-R Diagnostic and Statistical Manual of Mental Disorders, 3rd edition, Revision; $n / a$ not available

In all of the recruited studies, the diagnosis of $\mathrm{BD}$ was made according to the Diagnostic and Statistical Manual of Mental Disorders (DSM) [52]. The assays used to detect folate levels included chemiluminescent immunoassay, microparticle enzyme immunoassay, electrochemiluminescence immunoassay, solid phase radioassay, and the IMx system (Table 1). Concerning the methodological quality of the included studies, the median NOS score was 8 with 25-75\% quantile 7.25-8 (Additional file 1: Table S1).

\section{Main results of the current meta-analysis}

The results of the meta-analysis indicated that serum folate levels in the patients with BD were significantly lower than those in the controls $(k=6$, Hedges' $g=-0.211,95 \%$ $\mathrm{CI}=-0.391$ to $-0.031, p=0.021$ ) (Fig. 2) without significant evidence of heterogeneity $(\mathrm{Q}$ value $=8.647, \mathrm{df}=5$, $\left.I^{2}=42.177 \%, p=0.124\right)$ or publication bias via inspection of the funnel plot (Additional file 2: Figure S1) and Egger's regression test $(\mathrm{t}=1.428, \mathrm{df}=4, p=0.226)$. 
Table 2 Baseline characteristics of the recruited subjects in the individual studies

\begin{tabular}{|c|c|c|c|c|c|c|c|}
\hline Author (year) & $\begin{array}{l}\text { psychotropic } \\
\text { medication } \\
\text { use }\end{array}$ & $\begin{array}{l}\text { proportion of specific } \\
\text { medication }\end{array}$ & $\begin{array}{l}\text { Healthy Control group } \\
\text { criteria }\end{array}$ & $\begin{array}{l}\text { dietary } \\
\text { habit }\end{array}$ & $\begin{array}{l}\text { nutritional } \\
\text { status }\end{array}$ & $\begin{array}{l}\text { genetic } \\
\text { characteristics }\end{array}$ & Country \\
\hline $\begin{array}{l}\text { Doganavsargil } \\
\text { Baysal, G.O. } \\
\text { (2013) }\end{array}$ & yes & $\begin{array}{l}\text { lithium: } 11 \text { patients (18.33\%) } \\
\text { valproic acid:6 patients (10\%) } \\
\text { mood stabilizing drugs plus } \\
\text { antipsychotic drugs:30 } \\
\text { patients (50\%) two mood } \\
\text { stabilizing drugs: } 12 \text { patients } \\
(20 \%)\end{array}$ & $\begin{array}{l}\text { Subjects who had not } \\
\text { been diagnosed with a } \\
\text { psychiatric disease and } \\
\text { did not have a known } \\
\text { significant medical } \\
\text { condition or mental } \\
\text { development disorder }\end{array}$ & $\mathrm{n} / \mathrm{a}$ & $\mathrm{n} / \mathrm{a}$ & $\mathrm{n} / \mathrm{a}$ & Turkey \\
\hline $\begin{array}{l}\text { Ezzaher, A. } \\
\text { (2011) }\end{array}$ & yes & $\begin{array}{l}\text { Valproic acid: } 46 \text { patients } \\
\text { (50\%) Lithium: } 10 \text { patients } \\
\text { (10.9\%) Carbamazepine: } 9 \\
\text { patients (9.8\%) Valproic acid } \\
\text { and lithium: } 3 \text { patients (3.2\%) } \\
\text { Antipsychotics: } 24 \text { patients } \\
(26.1 \%)\end{array}$ & $\begin{array}{l}\text { None of the controls } \\
\text { had psychiatric illnesses, } \\
\text { epilepsy, mental } \\
\text { retardation, hormone } \\
\text { therapy, history of } \\
\text { vitamin use, diabetes, } \\
\text { cardiovascular disease, } \\
\text { thyroid dysfunction, } \\
\text { liver disease or renal } \\
\text { dysfunction. }\end{array}$ & $\mathrm{n} / \mathrm{a}$ & $\mathrm{n} / \mathrm{a}$ & $\begin{array}{l}\text { C677T MTHFR } \\
\text { polymorphism was studied } \\
\text { but no significant finding }\end{array}$ & Tunisia \\
\hline $\begin{array}{l}\text { Diass, V.V. } \\
\text { (2009) }\end{array}$ & yes & $\mathrm{n} / \mathrm{a}$ & $\begin{array}{l}\text { Healthy individuals were } \\
\text { screened for personal } \\
\text { and first-degree family } \\
\text { axis I psychiatric disor- } \\
\text { ders with the MINI. }\end{array}$ & $\mathrm{n} / \mathrm{a}$ & $\mathrm{n} / \mathrm{a}$ & $\mathrm{n} / \mathrm{a}$ & Spain \\
\hline $\begin{array}{l}\text { Ozbek, Z. } \\
\text { (2008) }\end{array}$ & yes & $\begin{array}{l}\text { Atypical antipsychotic: } 17 \% \\
\text { typical antipsychotic: } 65 \% \\
\text { atypical antipsychotic in } \\
\text { combination with typical } \\
\text { antipsychotic: } 18 \%\end{array}$ & $\begin{array}{l}\text { Healthy and unrelated } \\
\text { volunteers without } \\
\text { psychiatric disorders } \\
\text { were selected as a } \\
\text { control group. }\end{array}$ & $\mathrm{n} / \mathrm{a}$ & $\mathrm{n} / \mathrm{a}$ & $\begin{array}{l}\text { Patients carrying } T \text { and/or } \\
\text { AA and AC genotypes in } \\
\text { methylenetetrahydrofolate } \\
\text { (MTHFR) gene variants of } \\
\text { c.1298A > C (Glu429Ala) and } \\
\text { c.677C > T (Ala222Val) } \\
\text { reduced folate levels }\end{array}$ & Turkey \\
\hline $\begin{array}{l}\text { Lerner, V. } \\
\text { (2006) }\end{array}$ & yes & $\mathrm{n} / \mathrm{a}$ & $\begin{array}{l}\text { Subjects from } \\
\text { community clinics with } \\
\text { no record of psychiatric } \\
\text { illness }\end{array}$ & $\mathrm{n} / \mathrm{a}$ & $\mathrm{n} / \mathrm{a}$ & $\mathrm{n} / \mathrm{a}$ & Israel \\
\hline $\begin{array}{l}\text { Hasanah, C.I. } \\
\text { (1997) }\end{array}$ & $\begin{array}{l}\text { inpatient, n/ } \\
\text { a }\end{array}$ & $\mathrm{n} / \mathrm{a}$ & $\begin{array}{l}\text { The control group was } \\
\text { taken from the out- } \\
\text { patient clinic. Only pa- } \\
\text { tients with minor ail- } \\
\text { ments like headaches, } \\
\text { cough and cold were } \\
\text { taken. } \\
\text { Exclusion criteria for the } \\
\text { control group were, } \\
\text { family history and past } \\
\text { history of psychiatric } \\
\text { illness, substance } \\
\text { misuse, recent weight } \\
\text { loss, sleep disturbance, } \\
\text { pregnancy and } \\
\text { puerperium. }\end{array}$ & $\mathrm{n} / \mathrm{a}$ & $\mathrm{n} / \mathrm{a}$ & $\mathrm{n} / \mathrm{a}$ & Malaysia \\
\hline
\end{tabular}

\section{Sensitivity test}

The significant results of the meta-analysis did not become insignificance after removing any one of the included studies, except for the study by Ezzaher (2011, 47] (after removal of that study, Hedges' $g=-0.149$, $95 \% \mathrm{CI}=-0.349$ to $0.051, p=0.143$ ) or that by Ozbek (2008) (after removal of that study, Hedges' $g=-0.160$, $95 \% \mathrm{CI}=-0.401$ to $0.082, p=0.195)$ [48].

\section{Meta-regression}

The meta-regression could not be performed because of lack of sufficient datasets.

\section{Discussions}

To our knowledge, the current meta-analysis is the first study specifically focusing on the differences in folate levels between patients with $\mathrm{BD}$ and healthy controls. 


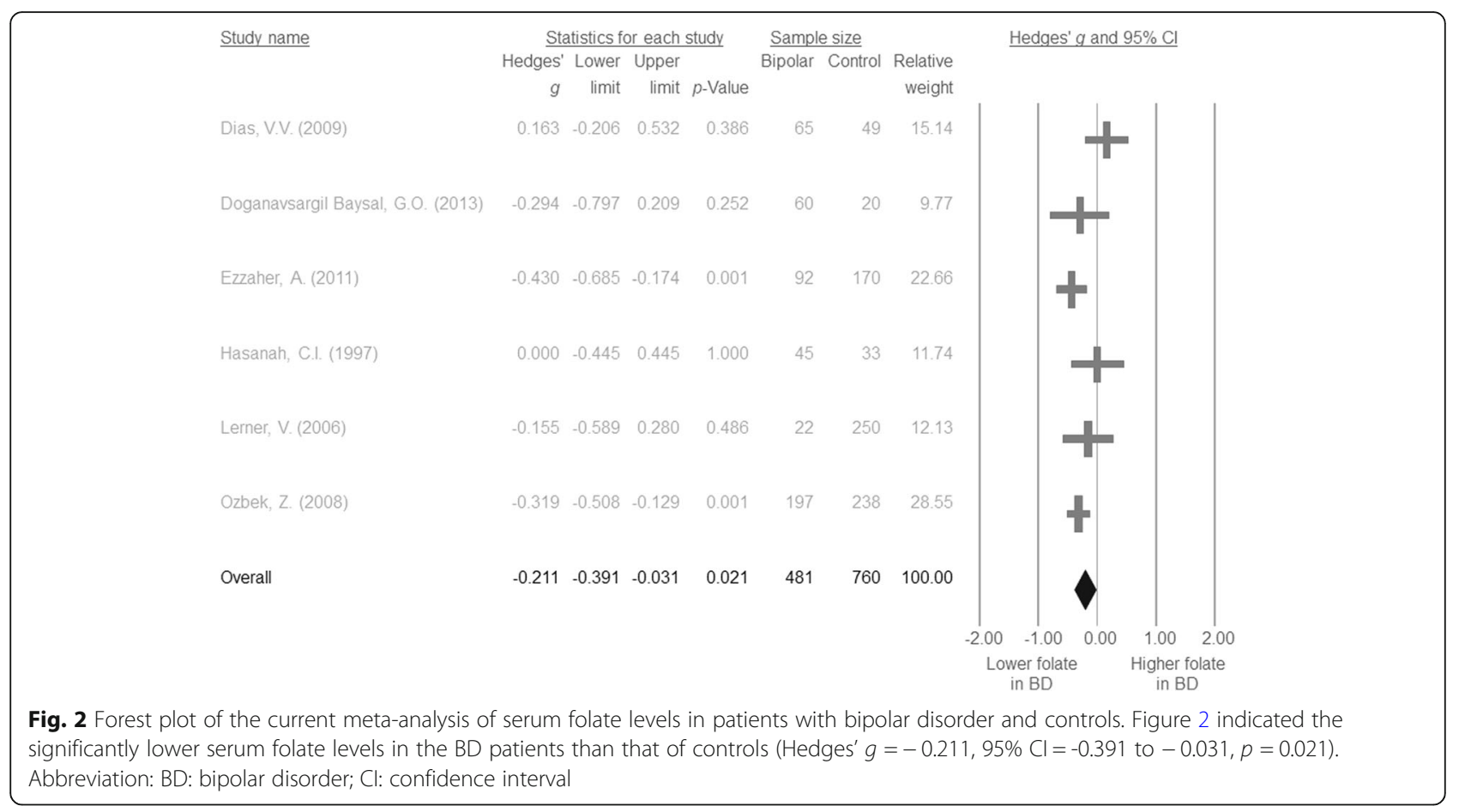

The current meta-analysis indicated that the patients with BD had significantly lower serum folate levels than the controls.

Our results showed significantly lower folate levels in the patients with $\mathrm{BD}$. There are two potential explanations for this finding. First, due to the biological role of folate, the biologically active form of folate, L-methylfolate, may act as a trimonoamine modulator and enhance the synthesis of three monoamines including dopamine, norepinephrine, and serotonin, and this has been reported to be involved in the efficacy of antidepressants [53]. The significantly lower folate level in the patients with BD could have been the result of dysregulation of methylenetetrahydrofolate reductase (MTHFR) enzyme, which is a product of the MTHFR gene [54]. A previous study also reported the role of MTHFR gene polymorphisms in the association between a low folate level and BD, [55] and another study reported that this was a potential risk factor for the development of BD [48]. Furthermore, a meta-analysis of MTHFR gene variants also provided evidence of epigenetic involvement in the pathophysiology of BD [56].

The other potential explanation may be due to malnutrition, as patients with $\mathrm{BD}$ have been reported to have deficient folate intake [57]. In an epidemiological and crosssectional survey, patients with BD had significantly poor dietary habits and malnutrition status [58]. Furthermore, patients with $\mathrm{BD}$ tend to consume unhealthy prepackaged or prepared food, which lacks sufficient levels of essential vitamins [22]. Another cross-sectional study also indicated a lower folate intake than the recommended daily allowance among patients with $\mathrm{BD}$ and major depressive disorder [57]. Following the rationale above, previous review based on randomized controlled studies provided the evidences about the benefit of folate supplement in manic patients [59]. Therefore, we suggest that clinicians should pay special attention to the nutritional status, including folate intake, of patients with $\mathrm{BD}$ which would be of clinical importance.

The relationship between folate levels and mood status had been widely explored, especially in patients with depressive mood [32]. The previous study of this relationship might be one possible explanation of our findings of lower folate levels in the patients with $\mathrm{BD}$, which consisted of depressive, manic, and mixed mood. However, due to few studies included, we could not perform further analysis to distinguish the relationship with folic acid and specific mood status.

\section{Limitations}

Several limitations should be addressed for the current meta-analysis. First, the overall meta-analytic results became insignificant during sensitivity test, which was not only due to the small sample sizes but also the small effect sizes. The possibility of both type I and type II errors cannot not be excluded. Also, an effect size around 0.2 was small, [60] which might not be relevant to clinically significant. Second, we could not perform sub-group analysis due to the limited number of comparison arms, such as different mood states of BD. Therefore, at current stage, we could not distinguish the potential effect of mood states on the folate levels. Third, because 
the association between $\mathrm{BD}$ and folate levels had not been well-established, there were only few clinical studies addressing this issue. Therefore, we could not perform further investigations into the dietary habit, nutritional status, prescription of psychotropic agents, and genetic characteristics because of too few studies to make subgroup analysis of the included BD patients because of a lack of data. Fourth, most of the included studies were cross-sectional studies, and progressive changes in folate levels could not be estimated. Fifth, the prescribed mood stabilizers and antipsychotics may have had a cofounding effect on the level of folate in the patients with BD [61], and this effect was not controlled in the included studies. Sixth, the power of the Egger's test with substantially fewer than 10 studies is not recommended [62]. Finally, as the natural limitation of metaanalysis, we could only observe a phenomenon but not explore the pathophysiology behind it.

\section{Conclusion}

The current meta-analysis show that there might be association between lower serum folate levels and patient with $\mathrm{BD}$. However, we could not distinguish the potentially confounding effects of mood states on the folate levels. Future investigations on potential differences in folate levels in BD patients with different mood states, and the potential physiopathology behind the folate deficiency and the etiology of BD should be warranted.

\section{Supplementary information}

Supplementary information accompanies this paper at https://doi.org/10. 1186/s12888-019-2269-2

Additional file 1: Table S1. Newcastle-Ottawa Scale (NOS) of recruited studies, Table S2. Excluded studies and reasons and Table S3. Database and keyword search strategy.

Additional file 2: Figure S1. Funnel plot of current meta-analysis.

\section{Abbreviations}

BD: Bipolar disorder; BDNF: Brain-derived neurotrophic factor; BMI: Body mass index; Cl: Confidence interval; DNA: Deoxyribonucleic acid; DSM: Diagnostic and Statistical Manual of Mental Disorders; ES: Effect size; MTHFR: Methylenetetrahydrofolate reductase; NOS: Newcastle-Ottawa scale; PRISMA: Preferred Reporting Items for Systematic Reviews and MetaAnalyses; SD: Standard deviation

\section{Acknowledgements}

We had contacted Dr. Fabria Chiarani and Dr. Elizabeth Tunbridge for request of detailed data, and we especially thanks for their help.

\section{Authors' contributions}

All authors made substantive intellectual contributions to this study to qualify as authors. $\mathrm{YCH}$, the first author, takes the responsibility of writing this manuscript. DJL and PTT, the corresponding authors, take all the responsibility of collecting all the information from all authors, analyze data, revise the manuscript, and submit the manuscript. LSC, CHL, and HCW contribute in the literature searching and screening. All authors read and approved the final manuscript.

\section{Funding}

No funds were received in support of this work.

\section{Availability of data and materials}

Specific data sets used and/or analyzed during the current study are available from the corresponding author on reasonable request.

\section{Ethics approval and consent to participate}

This study was approved by the Institutional Review Board at Kaohsiung Municipal Kai-Syuan Psychiatric Hospital. (Registration numbers: KSPH-N201706).

\section{Consent for publication}

Not applicable.

\section{Competing interests}

The authors declare that they have no financial or other conflicts of interests in relation to this manuscript.

\section{Author details}

'Kaohsiung Municipal Kai-Syuan Psychiatric Hospital, No.130, Kaisyuan 2nd Rd., Lingya Dist, Kaohsiung City 802, Taiwan. ${ }^{2}$ WinShine Clinics in Specialty of Psychiatry, Kaohsiung City, Taiwan. ${ }^{3}$ Prospect Clinic for Otorhinolaryngology \& Neurology, Kaohsiung City, Taiwan.

Received: 15 May 2019 Accepted: 3 September 2019

Published online: 22 October 2019

\section{References}

1. Judd LL, Akiskal HS, Schettler PJ, Coryell W, Endicott J, Maser JD, Solomon $\mathrm{DA}$, Leon $\mathrm{AC}$, Keller MB. A prospective investigation of the natural history of the long-term weekly symptomatic status of bipolar II disorder. Arch Gen Psychiatry. 2003:60(3):261-9.

2. Post RM, Altshuler LL, Frye MA, Suppes T, Keck PE Jr, McElroy SL, Leverich GS, Luckenbaugh DA, Rowe M, Pizzarello S, et al. Complexity of pharmacologic treatment required for sustained improvement in outpatients with bipolar disorder. J Clin Psychiatry. 2010;71(9):1176-86 quiz 1252-1173.

3. Suppes T, Kelly DI, Perla JM. Challenges in the management of bipolar depression. J Clin Psychiatry. 2005;66(Suppl 5):11-6.

4. Culver JL, Arnow BA, Ketter TA. Bipolar disorder: improving diagnosis and optimizing integrated care. J Clin Psychol. 2007;63(1):73-92.

5. Miklowitz DJ, Johnson SL. The psychopathology and treatment of bipolar disorder. Annu Rev Clin Psychol. 2006:2:199-235.

6. Keitner GI, Solomon DA, Ryan CE, Miller IW, Mallinger A, Kupfer DJ, Frank E. Prodromal and residual symptoms in bipolar I disorder. Compr Psychiatry. 1996;37(5):362-7.

7. Coryell W, Scheftner W, Keller M, Endicott J, Maser J, Klerman GL. The enduring psychosocial consequences of mania and depression. Am J Psychiatry. 1993:150(5):720-7.

8. Marangell LB, Dennehy EB, Miyahara S, Wisniewski SR, Bauer MS, Rapaport $\mathrm{MH}$, Allen $\mathrm{MH}$. The functional impact of subsyndromal depressive symptoms in bipolar disorder: data from STEP-BD. J Affect Disord. 2009; 114(1-3):58-67.

9. Morgan VA, Mitchell PB, Jablensky AV. The epidemiology of bipolar disorder: sociodemographic, disability and service utilization data from the Australian National Study of low prevalence (psychotic) disorders. Bipolar Disord. 2005; 7(4):326-37.

10. Murray CJ, Lopez AD. Global mortality, disability, and the contribution of risk factors: global burden of disease study. Lancet. 1997;349(9063):1436-42.

11. Murray CJL, Lopez AD, Harvard School of Public Health., World Health Organization., World Bank. The global burden of disease : a comprehensive assessment of mortality and disability from diseases, injuries, and risk factors in 1990 and projected to 2020. Cambridge: Published by the Harvard School of Public Health on behalf of the World Health Organization and the World Bank ; Distributed by Harvard University Press; 1996.

12. Alawieh A, Zaraket FA, Li JL, Mondello S, Nokkari A, Razafsha M, Fadlallah B, Boustany RM, Kobeissy FH. Systems biology, bioinformatics, and biomarkers in neuropsychiatry. Front Neurosci. 2012;6:187.

13. Domenici E, Wille DR, Tozzi F, Prokopenko I, Miller S, McKeown A, Brittain C, Rujescu D, Giegling I, Turck CW, et al. Plasma protein biomarkers for 
depression and schizophrenia by multi analyte profiling of case-control collections. PLoS One. 2010;5(2):e9166.

14. Frey BN, Andreazza AC, Houenou J, Jamain S, Goldstein BI, Frye MA, Leboyer M, Berk M, Malhi GS, Lopez-Jaramillo C, et al. Biomarkers in bipolar disorder: a positional paper from the International Society for Bipolar Disorders Biomarkers Task Force. Aust N Z J Psychiatry. 2013;47(4):321-32.

15. Fernandes BS, Gama CS, Cereser KM, Yatham LN, Fries GR, Colpo G, de Lucena D, Kunz M, Gomes FA, Kapczinski F. Brain-derived neurotrophic factor as a state-marker of mood episodes in bipolar disorders: a systematic review and meta-regression analysis. J Psychiatr Res. 2011;45(8):995-1004.

16. Molendijk ML, Spinhoven P, Polak M, Bus BA, Penninx BW, Elzinga BM. Serum BDNF concentrations as peripheral manifestations of depression: evidence from a systematic review and meta-analyses on 179 associations (N=9484). Mol Psychiatry. 2014;19(7):791-800.

17. Li H, Hong W, Zhang C, Wu Z, Wang Z, Yuan C, Li Z, Huang J, Lin Z, Fang Y. IL-23 and TGF-beta1 levels as potential predictive biomarkers in treatment of bipolar I disorder with acute manic episode. J Affect Disord. 2015;174:361-6.

18. Bartoli F, Crocamo C, Dakanalis A, Brosio E, Miotto A, Capuzzi E, Clerici M, Carra G. Purinergic system dysfunctions in subjects with bipolar disorder: a comparative cross-sectional study. Compr Psychiatry. 2017;73:1-6.

19. Bartoli F, Crocamo C, Mazza MG, Clerici M, Carra G. Uric acid levels in subjects with bipolar disorder: a comparative meta-analysis. J Psychiatr Res. 2016;81:133-9.

20. Elmslie JL, Mann Jl, Silverstone JT, Williams SM, Romans SE. Determinants of overweight and obesity in patients with bipolar disorder. J Clin Psychiatry. 2001;62(6):486-91 quiz 492-483.

21. Kilbourne AM, Rofey DL, McCarthy JF, Post EP, Welsh D, Blow FC. Nutrition and exercise behavior among patients with bipolar disorder. Bipolar Disord. 2007;9(5):443-52.

22. Lakhan SE, Vieira KF. Nutritional therapies for mental disorders. Nutr J. 2008;7:2.

23. Catoni GL. S-Adenosylmethionine; a new intermediate formed enzymatically from L-methionine and adenosinetriphosphate. J Biol Chem. 1953;204(1):403-16.

24. Farah A. The role of L-methylfolate in depressive disorders. CNS Spectrums. 2009:14(1 Suppl 2):2-7.

25. Torrey EF, Davis JM. Adjunct treatments for schizophrenia and bipolar disorder: what to try when you are out of ideas. Clin Schizophr Relat Psychoses. 2012;5(4):208-16.

26. Crider KS, Yang TP, Berry RJ, Bailey LB. Folate and DNA methylation: a review of molecular mechanisms and the evidence for folate's role. Adv Nutr. 2012;3(1):21-38.

27. James SJ, Miller BJ, Cross DR, McGarrity LJ, Morris SM. The essentiality of folate for the maintenance of deoxynucleotide precursor pools, DNA synthesis, and cell cycle progression in PHA-stimulated lymphocytes. Environ Health Perspect. 1993:101(Suppl 5):173-8.

28. Stahl SM. L-methylfolate: a vitamin for your monoamines. J Clin Psychiatry. 2008;69(9):1352-3.

29. Lerner V, Kanevsky M, Dwolatzky T, Rouach T, Kamin R, Miodownik C. Vitamin B12 and folate serum levels in newly admitted psychiatric patients. Clin Nutr. 2006;25(1):60-7.

30. Chiarani F, Tramontina JF, Cereser KM, Kunz M, Paim L, Vargas CR, Sitta A, Machado SP, Wyse AT, Kapczinski FP. Homocysteine and other markers of cardiovascular risk during a manic episode in patients with bipolar disorder. Rev Bras Psiquiatr. 2013;35(2):157-60.

31. Tunbridge EM, Attenburrow MJ, Gardiner A, Rendell JM, Hinds C, Goodwin GM, Harrison PJ, Geddes JR. Biochemical and genetic predictors and correlates of response to lamotrigine and folic acid in bipolar depression: analysis of the CEQUEL clinical trial. Bipolar Disord. 2017;19(6):477-86.

32. Gillbody S, Lightfoot T, Sheldon T. Is low folate a risk factor for depression? A meta-analysis and exploration of heterogeneity. J Epidemiol Community Health. 2007;61 (7):631-7.

33. Belbasis L, Kohler CA, Stefanis N, Stubbs B, van Os J, Vieta E, Seeman MV, Arango C, Carvalho AF, Evangelou E. Risk factors and peripheral biomarkers for schizophrenia spectrum disorders: an umbrella review of meta-analyses. Acta Psychiatr Scand. 2018;137(2):88-97.

34. Liberati A, Altman DG, Tetzlaff J, Mulrow C, Gotzsche PC, loannidis JP, Clarke M, Devereaux PJ, Kleijnen J, Moher D. The PRISMA statement for reporting systematic reviews and meta-analyses of studies that evaluate health care interventions: explanation and elaboration. PLoS Med. 2009;6(7):e1000100.

35. Lazarou C, Kapsou M. The role of folic acid in prevention and treatment of depression: an overview of existing evidence and implications for practice. Complement Ther Clin Pract. 2010;16(3):161-6.
36. Marx W, Moseley G, Berk M, Jacka F. Nutritional psychiatry: the present state of the evidence. Proc Nutr Soc. 2017:76(4):427-36.

37. Rakofsky JJ, Dunlop BW. Review of nutritional supplements for the treatment of bipolar depression. Depress Anxiety. 2014;31(5):379-90.

38. Salagre E, Vizuete AF, Leite M, Brownstein D, McGuinness A, Jacka F, Dodd S, Stubbs B, Köhler C, Vieta E. Homocysteine as a peripheral biomarker in bipolar disorder: a meta-analysis. Eur Psychiatry. 2017;43:81-91.

39. Sylvia LG, Peters AT, Deckersbach T, Nierenberg AA. Nutrient-based therapies for bipolar disorder: a systematic review. Psychother Psychosom. 2013;82(1):10-9.

40. Converting Among Effect Sizes. https://www.meta-analysis.com/downloads/ Meta-analysis\%20Converting\%20among\%20effect\%20sizes.pdf.

41. Anglin RE, Samaan Z, Walter SD, McDonald SD. Vitamin D deficiency and depression in adults: systematic review and meta-analysis. Br J Psychiatry. 2013:202:100-7.

42. Tobias A. Assessing the influence of a single study in meta-analysis. Stata Tech Bull. 1999:47:15-7.

43. Higgins JP, Thompson SG. Quantifying heterogeneity in a meta-analysis. Stat Med. 2002;21(11):1539-58.

44. Higgins JP, Green S. 10.4.3.1 Recommendations on testing for funnel plot asymmetry. In: Higgins JP, Green S, editors. Cochrane Handbook for Systematic Reviews of Interventions. 5.1.0 ed. Cochrane Library; 2011. https://www.cochrane.org/.

45. Egger M, Davey Smith G, Schneider M, Minder C. Bias in meta-analysis detected by a simple, graphical test. Bmj. 1997;315(7109):629-34.

46. Duval S, Tweedie R. Trim and fill: a simple funnel-plot-based method of testing and adjusting for publication bias in meta-analysis. Biometrics. 2000;56(2):455-63.

47. Ezzaher A, Mouhamed DH, Mechri A, Omezzine A, Neffati F, Douki W, Bouslama A, Gaha L, Najjar MF. Hyperhomocysteinemia in Tunisian bipolar I patients. Psychiatry Clin Neurosci. 2011;65(7):664-71.

48. Ozbek Z, Kucukali Cl, Ozkok E, Orhan N, Aydin M, Kilic G, Sazci A, Kara I. Effect of the methylenetetrahydrofolate reductase gene polymorphisms on homocysteine, folate and vitamin B12 in patients with bipolar disorder and relatives. Prog Neuro-Psychopharmacol Biol Psychiatry. 2008;32(5):1331-7.

49. Doganavsargil Baysal GO, Gokmen Z, Akbas H, Cinemre B, Metin O, Karaman T. Association of serum homocysteine and methionine levels with cognition and functioning in bipolar disorder. Turk Psikiyatri Derg. 2013;24(1):7-16.

50. Hasanah Cl, Khan UA, Musalmah M, Razali SM. Reduced red-cell folate in mania. J Affect Disord. 1997:46(2):95-9.

51. Dias W, Brissos S, Cardoso C, Andreazza AC, Kapczinski F. Serum homocysteine levels and cognitive functioning in euthymic bipolar patients. J Affect Disord. 2009;113(3):285-90

52. APA. Diagnostic and statistical manual of mental disorders. 5th ed. Arlington: American Psychiatric Publishing; 2013.

53. Stahl SM. Novel therapeutics for depression: L-methylfolate as a trimonoamine modulator and antidepressant-augmenting agent. CNS Spectr. 2007;12(10):739-44

54. Botto LD, Yang Q. 5,10-methylenetetrahydrofolate reductase gene variants and congenital anomalies: a HuGE review. Am J Epidemiol. 2000;151(9):862-77.

55. Kempisty B, Mostowska A, Gorska I, Luczak M, Czerski P, Szczepankiewicz A, Hauser J, Jagodzinski PP. Association of 677C $>$ T polymorphism of methylenetetrahydrofolate reductase (MTHFR) gene with bipolar disorder and schizophrenia. Neurosci Lett. 2006;400(3):267-71.

56. Peerbooms OL, van Os J, Drukker M, Kenis G, Hoogveld L, Group MiP, de Hert M Delespaul P, van Winkel R, Rutten BP. Meta-analysis of MTHFR gene variants in schizophrenia, bipolar disorder and unipolar depressive disorder: evidence for a common genetic vulnerability? Brain Behav Immun. 2011;25(8):1530-43.

57. Davison KM, Kaplan BJ. Vitamin and mineral intakes in adults with mood disorders: comparisons to nutrition standards and associations with sociodemographic and clinical variables. J Am Coll Nutr. 2011;30(6):547-58.

58. Abdulle AM, Pathan JY, Moussa N, Gariballa S. Association between homocysteine and endothelial dysfunction markers in stroke disease. Nutr Neurosci. 2010;13(1):2-6.

59. Fusar-Poli L, Surace T, Vanella A, Meo V, Patania F, Furnari R, Signorelli MS, Aguglia E. The effect of adjunctive nutraceuticals in bipolar disorder: a systematic review of randomized placebo-controlled trials. J Affect Disord. 2019;252:334-49.

60. Sullivan $G M$, Feinn R. Using effect size-or why the P value is not enough. J Grad Med Educ. 2012;4(3):279-82.

61. Misiak B, Frydecka D, Laczmanski L, Slezak R, Kiejna A. Effects of secondgeneration antipsychotics on selected markers of one-carbon metabolism 
and metabolic syndrome components in first-episode schizophrenia patients. Eur J Clin Pharmacol. 2014;70(12):1433-41.

62. Higgins J, Green S. In: Higgins J, Green S, editors. Cochrane Handbook for systematic reviews of interventions: The Cochrane Collaboration; 2009.

https://www.cochrane.org/.

\section{Publisher's Note}

Springer Nature remains neutral with regard to jurisdictional claims in published maps and institutional affiliations.

Ready to submit your research? Choose BMC and benefit from:

- fast, convenient online submission

- thorough peer review by experienced researchers in your field

- rapid publication on acceptance

- support for research data, including large and complex data types

- gold Open Access which fosters wider collaboration and increased citations

- maximum visibility for your research: over $100 \mathrm{M}$ website views per year

At $\mathrm{BMC}$, research is always in progress.

Learn more biomedcentral.com/submissions 